\title{
Strategic Groups and State Capacity: The Case of the Private Entrepreneurs
}

\section{Thomas Heberer}

\section{Q OpenEdition}

12 Journals

Édition électronique

URL : http://journals.openedition.org/chinaperspectives/255

DOI : 10.4000/chinaperspectives.255

ISSN : 1996-4617

Éditeur

Centre d'étude français sur la Chine contemporaine

\section{Édition imprimée}

Date de publication : 15 avril 2003

ISSN : 2070-3449

Référence électronique

Thomas Heberer, «Strategic Groups and State Capacity: The Case of the Private Entrepreneurs », China Perspectives [En ligne], 46 | march-april 2003, mis en ligne le 23 novembre 2006, consulté le 28 octobre 2019. URL : http://journals.openedition.org/chinaperspectives/255 ; DOI : 10.4000/ chinaperspectives. 255

Ce document a été généré automatiquement le 28 octobre 2019

(C) All rights reserved 


\title{
Strategic Groups and State Capacity: The Case of the Private Entrepreneurs
}

\author{
Thomas Heberer
}

1 From the perspective of a centralised state, state capacity refers to the capability a state has to enforce political decisions. More recent approaches to defining this phrase involve deconstructing the concept of 'state' and concentrating on the interaction between state and society. Actor-centred institutionalism assumes that social phenomena are to be understood to be the product of interactions of intentional acts between individual, collective or corporatist actors ${ }^{1}$. The relationship between state and society is by no means merely a relationship between central state and the whole of society, as both are subdivided on the vertical and horizontal levels. Thus, different levels and organisations may have different capacities. It therefore appears practical to conceive the state as an ensemble of various organisations interacting with society at various levels ${ }^{2}$. In this sense state capacity is much more shaped by inner tensions and conflicts ${ }^{3}$.

2 Frequently, the notion of capacity implies a perception of the state as a uniform and homogeneous phenomenon. New approaches argue in a more differentiated way and deconstruct the concept of state capacity. "Capacity for what?", asks Linda Weiss, arguing that a general notion of state capacity makes no sense, as states are stronger in one area and weaker in others, thus, solely policy-oriented capacities do exist. State capacity is not primarily the capability to enforce goals, but rather has to be comprehended as a "product of institutions governing domestic linkages" ${ }^{4}$. This institutional approach was enhanced by Peter Evan's concept of embedded autonomy. According to this concept, in order to achieve transformational goals, states are not only successful if they act autonomously, they are also successful if this autonomy is embedded in distinct social ties linking the state to society, thus enabling the implementation of policies ${ }^{5}$. 
In China, under present conditions of economic and social liberalisation that have led to the emergence of new social groups and differentiated interests, state capacity, in the sense of organising a state, requires two further elements, which are urgently demanded by various social groups: learning capabilities and bargaining competence. Obviously, state capacity in China currently is more than power of enforcement, as it also encompasses bargaining power. As far as the function of the state is concerned, state capacity has increasingly to be comprehended as the capacity to incorporate new social groups, associations and organisations into bargaining processes and to find a balance between various particularistic interests. State learning, i.e. the conclusions drawn by the state out of past mistakes and failures that might result in different or improved policies is part of that ability. Hence we may speak of an adjustment to situational and political changes. Learning in this sense means finding new solutions for problems, that are acceptable to state's actors. This implies various stages of learning and various dimensions of learning processes ${ }^{6}$.

4 In this sense state capacity comprises the following elements (primarily in terms of domestic political processes): Legitimacy in the sense of the legitimation of the political system accepted by its citizens; regulating and controlling capacity in the sense of social control und regulation; resources for enforcement (financial and coercive means as well as personnel resources); bargaining capacity, i.e. the ability to incorporate new social groups, associations and organisations into bargaining processes and to find a balance between various particularistic interests; learning capacity, i.e. the ability to learn from mistakes and failures.

5 If state capacity has to be discerned as part of an interaction relationship between state and society, we may see two perspectives of that capacity: that of the state and that of society or its actors. Such an understanding from "below" necessarily is interest-led and tends to an articulation of interests. And interest articulation tends to influence state capacities. In this article this will be examined in the light of the interaction between state and private entrepreneurs ${ }^{7}$. We argue that the new private entrepreneurs constitute strategic groups with distinct interests who develop a transformational as well as strategic potential. In turn this potential affects state capacity.

6 The interrogation that will be addressed is whether or not the strategic groups of entrepreneurs contribute significantly to the alteration of the structures and capacity of the state. The entrepreneurs' strategy is interest-led as they act with a view to realising their expectations. This does not mean that the political system is fundamentally put into question or weakened. Furthermore, entrepreneurs on the one hand contribute to the reinforcement of state capacity, and on the other they make efforts to steer it in a certain direction. Before drawing any conclusions on the impact entrepreneurs have on state capacity we will examine the goals of the strategic groups of entrepreneurs.

7 The Sixteenth Party Congress of the Chinese Communist Party (CCP) in November 2002 decided that in the future private entrepreneurs would be allowed to join the Party. For many years such a step would have been considered a violation of the statutes of the Party. The lifting of this ban constitutes the end of a long development of the classification of entrepreneurs from "class enemy" to social role model. The question arises as to whether or not this development was initiated by an enlightened Party 
leadership or rather was the outcome of the strategic behaviour of the social actors concerned.

Entrepreneurs: strategic groups with group interests

8 The concept of strategic groups indicates a group of people linked by a common interest in protecting or enhancing their common chances of appropriation. Appropriation in this sense does not refer only to material goods, but also to immaterial ones such as power, prestige, knowledge, etc. The members of such groups share a distinct strategy of acting and the self-understanding to eventually constitute on the long run an important social actor ${ }^{8}$. Strategic groups are not solid classes, but rather groups in a developing process which, by organising themselves in associations act in a potentially strategic way. This concept also reaches beyond the ordinary interest groups. Strategic groups do not intend to achieve limited interests within a short time, but conceive themselves as an essential force in the balance of power of all strategic groups within an entire society $\left({ }^{9}\right)$, that in the long run and interacting with other social groups wish to enforce certain economic, social and even political purposes.

Strategic groups emerge primarily under conditions of social change and transformation, i.e. in periods with a high degree of social mobility. New social groups and new opportunities of appropriation arise. Strategic groups attempt to improve those opportunities by altering and reshaping the framework to suit their own interests. Such activities are necessarily political, to the extent that strategic groups could be classified as a kind of political actor. Concurrently, they work to form coalitions with other strategic groups.

The term 'strategic' refers to the designing and planned implementation of a long-term overall concept with the purpose of realising distinct objectives, such as material interests (such as profit or material goods), symbolic (prestige) and cognitive interests (values and self-realisation). Therefore, those aims are necessarily multi-dimensional, as [since] not only economic, but also political and social objectives[,] are aimed for. This multi-dimensionality is necessary, as optimal opportunities of appropriation and development are not only guaranteed through acceptance of economic development processes by the state, but also make demands upon legal and political protection, social acceptance and political influence.

11 If we apply the concept of strategic groups to the political arena, it becomes obvious that a group with common features and collective interests and goals has the aim of realising those goals in order to achieve advantages in the social struggle for distribution (Verteilungskampf) and in the improvement of the framework necessary to win that struggle. Certainly, it might be secondary depending on whether or not the enforcement of interests and goals is pursued as a conscious strategy or in the form of gradual collective actions with the aim of realising partial goals and partial strategies, whereas more far-reaching strategic goals are achieved gradually. According to the respective options which a group possesses objectively and subjectively, its goal ranges extend between the poles of co-operative system-inherent and system-opposing behaviour. Accordingly, Evers speaks of embeddedness in a paradigm of power. Strategic groups, he argues, possess the power to shape a society, an economy and a political system in such a way that provides them the optimal preconditions for the long-term appropriation of resources ${ }^{10}$. By power we do not mean political power by virtue of enforcing power in formal institutions or threat or refusal capacity, but rather 
informal power i.e., enforcement of interests outside formal enforcement hierarchies as well as to the consciousness of economic power in order to shape and enforce interests.

Chinese entrepreneurs exert power and influence by virtue of individual or collective behaviour, in the market and in political life. Economically, this occurs through decisions in terms of investments, location, production and employment. Such decisions influence the political setting and thus political decisions on the local and regional level. Socially they achieve this by offering donations and support, politically through networks, guanxi, institutional participation and corruption. This may be exerted individually or collectively, e.g. by means of associations or interest institutions. Larger entrepreneurs occupy official positions concurrently. In authoritarian states like China where active collective action is deemed to be sensitive and might easily be outlawed, particularly in the political domain, entrepreneurs perceive political forms of collective action merely to be the second best option.

Strategies are neither pursued in the interest of gaining political power nor do they challenge that power. My own survey in China revealed that there are clear and various strategies: growth strategies (in the interests of growth of a group or its organisations), strategies of businesses (to enforce market or business interests), stability strategies (in the interests of social or group stabilisation), politically defensive strategies (to prevent disadvantages), politically offensive strategies (to enforce formal or informal interests) or a combination of strategies. As the selection of strateg(y/ies) depends on the concrete situation, we cannot determine one unilinear or uniform behaviour of entrepreneurs as a group.

14 In fact, entrepreneurs do not form a unified homogenous group. There are very different categories such as large, medium and small entrepreneurs, successful and unsuccessful, or entrepreneurs who move on a scale between the poles of activeoptimistic and passive-pessimistic. There are entrepreneurs from the local Party or government bureaucracy (origin: 'cadre') and who have high-level relationships, and those without such relationships. There are push entrepreneurs who became selfemployed because they were dissatisfied with the working conditions in their earlier company, and pull entrepreneurs who are attracted by the entrepreneurial effect and its social and financial possibilities, and who consequently gave up their jobs. We can subdivide these too, according to reason for choosing self-employment as follows: (a) the use of market opportunities and market incentives (above all in urban areas and in more developed regions); (b) due to blocked opportunities to climb the ladder (selfemployment as an alternative path for social upward mobility); (c) advantages from opportunities (privileges and social relationships) by members of the political elite and sub-elite (above all at the local level); or (d) survival strategies (unemployed, pensioners) ${ }^{11}$. Therefore, strategies and strategic goals may vary according to a situation and a group's features ${ }^{12}$.

15 Strategic groups or their representatives have to be able to process information, to formulate groups' objectives, to put forward and implement goal-oriented decisions. The collecting of strategic information and strategic analyses, strategic planning and the implementation of that planning are necessary attributes of strategic groups and their interest organisations. The primary purpose of strategic planning is to select measures that ensure achievement of the objective envisaged ${ }^{13}$. 

long-term pursuing of targets becomes evident, but also the importance of the leadership of a strategic group having the necessary meta-cognition at its disposal. Strategic implementation might not always take place in a rational and thought-out manner, and can be spontaneous and unstructured in the initial phase. This implies that strategic acting is not an a priori existing feature, but is rather a learning process implementing itself in an interaction between organisation and group as well as between organisation and environment ${ }^{14}$. Thus, the notion of strategy reaches beyond its original military meaning [acceptation], meaning rather a programme's strategy. In this way it comes close to the concept of policy. phenomenon of entrepreneurs as a social group in China today. Five elements are crucial in determining a strategic group: 1. A group possesses an important function for the development of the entire society and for its political change and development. 2. It acts by means of an organised interest group with political bargaining capacity. 3. It acts strategically in the above-mentioned sense and possesses capabilities for formal and informal strategic enforcement. 4. The interest organisations possess strategic knowledge, strategic planning ability and a capacity to implement this planning. 5 . Habits and attitudes of the groups' members have an effect on value-building and value change.

18 The latter point in particular reveals that entrepreneurs are not only collective actors but also collective symbols. Keller pointed to three levels of those symbols: cognitive symbols (professionalism and knowledge), moral symbols (values and attitudes) and expressive symbols (emotions, modes of behaviour) ${ }^{15}$. Thus, entrepreneurs are examples for society and individuals, either as models or as bearers of hope. On the one hand they act collectively by means of their interest organisation, on the other hand they are symbolically representing economic authority, professionalism, economic decisionmaking, entrepreneurial success, wealth and a distinct lifestyle. The symbolism includes specific moral expectations (employer offering employment, fostering social welfare, social-oriented behaviour), distinct perceptions of values and order. The creation of such a symbolic character might be explained by means of a concrete example. In the Renmin Ribao, the Party mouthpiece, an entrepreneur at the end of 1999 argued that entrepreneurs of the twenty-first century had to act as politicians (zhengzhijia), thinkers (sixiangjia) and artists (yishujia) at the same time: as politicians, as their acting was inseparably linked to politics in the sense of participating in the creation of a political and legal framework; as thinkers, as the development of an enterprise would depend on the entrepreneur's philosophy, and as artists, as they had to approach people with empathy and understanding ${ }^{16}$. As in many press articles written by entrepreneurs the universal, strategic and exemplary character of entrepreneurship is emphasised, thus creating a role of a social model. The concept of strategic groups, besides strategic acting, contains the feature of strategic symbolism (entrepreneurs as symbols of a distinct behaviour and particular values).

19 The strategic-active part of entrepreneurship refers to larger, more important and better-educated entrepreneurs, often inhabiting public functions. This segment of entrepreneurship is more self-confident than smaller businesspeople, especially if people from the upper strata are involved. The more confident people are the more pro-active manner and the more energetic they are in realising their interests in a 
strategic way. It is this group that comprises the core of a strategic elite with a leadership function and that takes over the function of accepted spokespersons and representatives of the collective strategic group of entrepreneurs. Undoubtedly, entrepreneurs are developing into an economic elite, though not automatically into a strategic one. Social climbers, i.e. people lower down the social ladder, individual labourers or people once classified as political or social deviants often hesitate or are afraid about becoming involved politically or socially, and attempt to behave in a politically conformist manner. Chinese investigations reveal that individual (i.e. very small-scale) entrepreneurs (getihu) are more inclined to conceive politics as something negative (e.g. 'politics is a bad thing' or 'politics is the concern of a small minority only') and thus tend to be politically more indifferent than larger entrepreneurs.

The critique that the strategic group approach refers to an indistinct unit of reference does not apply to our group of actors, as despite all differences entrepreneurs consist of a distinctly differentiated group with similar features of identification. Thus, they differ from vague group concepts like 'middle classes' or 'bureaucracy' and might be classified in an analytically distinct manner. Certainly, this does not mean that as individuals they think and act in a uniform way, but rather that they organise themselves in interest associations, thus attempting to implement and achieve common goals. Those interest associations represent the will and necessity of collective acting of entrepreneurs ${ }^{17}$. The formation of a strategic group is a process. As far as our case is concerned, the process of entrepreneur group formation is not yet finished, but is rather an ongoing process, as an entrepreneurship is still an emerging status.

22 In order to substantiate our argument that the enforcement of common goals affects state capacity, first of all we have to identify group objectives of entrepreneurs. The concept of 'strategy' implies that a group attempts to enforce group targets in a planned or spontaneous manner. Certainly, Olson has in principle called into question whether or not groups pursue collective aims, as they were characterised, 'by the fact that, if one member does or does not help provide the collective good, no one other member will be significantly affected and therefore none has any reason to react. Thus an individual in a 'latent' group...cannot make a noticeable contribution to any group effort, and since no one in the group will react if he makes no contribution, he has no incentive to contribute' ${ }^{18}$.

23 This means that rational individuals would enjoy a free ride in such institutions. Common interests do exist, but they do not necessarily lead to mobilisation of the group, something that was classified as 'collective action dilemma' ${ }^{19}$. Yet, the similarity of interests makes such groups potential groups for organisation and mobilisation. The Chinese pattern of development might validate that view. Initially, an entrepreneurship emerged spontaneously and in deviation from official policies. The aim to make large profits as quickly as possible fostered thinking ability in individualoriented categories of entrepreneurs, particularly under conditions of long-term economic uncertainty, and in addition, the need to adapt to the political conditions and to develop guanxi and networks for business success. But if we turn to the processual character of entrepreneurship, we receive a more relativised picture. The history of the revitalisation of private entrepreneurship could be classified in the following phases: a) existence of a shadow economy; b) efforts to be officially accepted; c) substituting political with economic control (20); and d) legal protection and equality. Meanwhile, 
entrepreneurship is no longer part of the shadow economy, acceptance is steadily increasing, substitution by economic leverages for political leverages and legal protection have made significant progress. At present it is the themes of legal security, political participation and political equality that matter, the common collective goods in which private entrepreneurs are mostly interested.

Organisational capability as a precondition of effective organisation in interest associations demands three essential features: continuity of interest pursuance (in order to achieve a goal), urgency of realisation of interests, and common ground of interests. The organisation of entrepreneurs in interest associations is a manifestation of a group's consciousness or, as far as forced membership exists, it fosters the emergence of such a consciousness. Our interviews demonstrate that entrepreneurs, by means of those organisations, pursue the goal of enforcing common interests and aims through continuous acting ${ }^{21}$.

Organisational capability in the sense of the above-mentioned three features has grown by means of the following factors:

- Through forced membership in quasi state- or authority-controlled organisations. Hence, entrepreneurs were embedded in a trans-entrepreneurial context that resulted in the emergence of new networks, co-operation and sources of information. Concurrently, among some entrepreneurs a common identity was generated: the realisation that common interests and performance are necessary and that interest organisations-particularly selfadministered ones-were indispensable. Collective identity in that sense is defined by shared definitions of a group that 'derive from members' common interests and solidarity' 22 .

- The acceptance of the private sector by the state, its legal equality and ideological acceptance, finally its economic success has fostered confidence among entrepreneurs and the setting-up of mobilising activities aimed at raising its social and political prestige by means of the media and various institutional channels.

- Persistent intervention in entrepreneurial activities by local authorities, widespread corruption, the discrepancy between the supporting policies of the central authorities and the provinces on the one hand, and the sometimes rigid behaviour of local authorities on the other lead to high costs that in the long term are detrimental to the development of enterprises. 'Arbitrariness cannot be overcome by individual actions alone', as one entrepreneur argued. The interaction of political acceptance (at the central level), economic and social necessity (private sector as the most dynamic sector which from the perspective of employment and tax income is indispensable), and entrepreneurial confidence foster the organisational process too. Not a few entrepreneurs realised that organisation is not only confined to consultation, i.e. transmitting economic opinions to the authorities, but also lobbying has to be done and economic and regulatory policies (Ordnungspolitik) have to be influenced in the interest of entrepreneurs.

How group aims are enforced

By means of some case studies, e.g. by means of strategic efforts of entrepreneurs in terms of legal security, I will demonstrate in which manner entrepreneurs enforce group objectives and thus attempt to have an impact upon the framework and direction of state capacity. At the sessions of the National People's Congress and the National People's Consultative Conference ${ }^{23}$ in March 1998 a majority of those deputies who are private entrepreneurs voted for an alteration of the constitution in terms of a constitutional equalisation of the private sector. This was justified by the benefits 
which this sector brings to the national economy and employment as well as the increase in export capacities and foreign exchange. Concurrently, the establishing of a 'Bureau for Private Economy' was suggested, in order to raise the status of that sector within the administration and to offer the option of using that bureau in order to aid the pursuance of interests. An entrepreneur, deputy of the National People's Congress argued vis-à-vis the author of this paper:

For many years we have strived for the equal acceptance of this sector. This equality should be written into the Constitution. For us this is an important goal that implies a certain degree of political and legal security in the event it is actually realised. Primarily we attempted to convince them in the framework of the Association of Industry and Commerce and in many discussions with the United Front Department of the Central Committee of the Party [the department responsible for that association]. Certainly, we are discussing this among ourselves and thus reaching an agreement on how to argue and how to proceed. Our activities as deputies make access to political leaders and influential personalities possible and provide us with the opportunity to put forward and explain our opinions and to ask for support. This is the Chinese and our way of politics. It enables us to assert our opinions gradually and to shape policies in our own interests ${ }^{24}$.

As important bearers of state capacity it is not only the state, but also the Party that is the target of entrepreneurial acting. In Zhongguo Gongshang Bao, a daily newspaper published by the National Bureau for the Administration of Industry and Commerce with a weekly supplement for the private economic sector that claims to be the 'voice' of entrepreneurs, entrepreneurs frequently stress that their interests should be represented within the Party. In another contribution entitled, 'We want Party representatives', published by the Xinhua news agency, it was argued that the economic importance of entrepreneurship within the general development strategy of the country would require such a step. The argumentation was accompanied by ideological support: 'It is the reform and opening policy initiated by the Party that provided us with all we have gained till today. Only if we go along with the Party the road will become broader and broader' ${ }^{25}$.

Here an analysis is used to illustrate the legal framework according to which entrepreneurs pursue strategic goals beneficial to them, thus affecting the state's capacity in the area of law. Market economy and its opening policy require new rules. The private sector needs legal protection in order to develop. Political protection has to be replaced by legal protection. Laws need legal institutions in order to be enforceable. Integration into the global economy and economic globalisation require increasing adaptation in terms of international legal norms and standards. Entrepreneurs are not the sole actors but rather those who are most interested in a stable and solid economic law, as their enterprises cannot develop and consolidate without such laws. The emergence of entrepreneurship was beneficial to the further change of a law culture: until the 1990s it was not individual entrepreneurs or entrepreneurs with property rights, but rather the enterprise as an institution ${ }^{26}$ that according to the law was a legal subject. Meanwhile it is accepted in China that entrepreneurs have to be supported by laws which safeguard their interests and their economic activities effectively, and to prevent the exit of private entrepreneurs from economic life. Therefore, it is no longer corporate economic law that counts, but increasingly individual economic rights. The latter have to be discerned as a preliminary stage of the discussion on individual rights. 

of the tasks of Party and state had the effect such that the NPC could take over competences in fields that were considered to be secondary in terms of the political system. The same holds for legality, insofar as it has no contra-systemic effects, i.e. so long as it is not directed against the power of the Party. Certainly, the Party leadership is the last resort of decision-making, but meanwhile it tolerates moderate forms of dissent. Therefore, state and Party are less a structure but rather a process. Neither the Party nor the State Council or the People's Congress constitute an unity, but have to be deconstructed in vertical (regional, local) and horizontal entities (Party, State Council, NPC, Political Consultative Conferences, etc.) interacting with each other and permanently changing. It is this that constitutes the processive character (Prozesscharakter) of those institutions. Tanner, accordingly, speaks of three arenas in legislative procedures: People's Congress, State Council and Party leadership. The Political Consultative Conference is an ally of the People's Congress as it operates relatively independently, is not so strictly controlled and possesses a merely consultative function, though it is concurrently embedded in consultative decisionmaking processes.

33 Tanner refers to the 'Garbage Can' model of Cohen, Olson and March, according to which complex organisations temporarily constitute a form of organised anarchy. Such 
organised anarchies are characterised by indistinct goal hierarchies. The system of decision-making is inefficient, as now distinct rules and procedures for decisionmaking are established. Decision insecurity was prevalent among the actors involved, and it became impossible to predict decisions. Furthermore, the principal actors of decision-making were not unequivocally and regularly participating in decisionmaking. Tanner compares the Chinese legislative process with this form of organised anarchy arguing that the differentiation of the social system dissolves vertical decisionmaking processes in interactive and bargaining systems and disperses power and decision-making processes ${ }^{28}$. This hypothesis seems to prove right in practice.

Let us look at the process of interest representation of entrepreneurs in terms of legislation. The Zhongguo Gongshang Bao reported on a law protecting the economic rights and interests of private economy that by means of the Association of Industry and Commerce was put forward to the national congress of the Political Consultative Conference in spring 1998. In the application it was argued in a tactically clever manner: the Association [and not the entrepreneurs!] would hold the opinion that the non-public economy which had been declared to be an important part of the socialist market economy [by the Fifteenth Party Congress] had developed to a certain degree. Political support alone was no longer sufficient, but instead legal protection was required. Had it not been argued this way it would be difficult to implement the policy of the Party in a stability-oriented and resolute way. Ownership and the property of those concerned should enjoy legal protection. Illegal interference was detrimental to the further 'healthy' development of the private sector. Only public but not private ownership was protected by the Constitution. Fortunately, Canton had issued a respective law securing autonomous operation of private businesses, intellectual property, investment, employment rights, foreign trade rights, private property and other rights. This law, so argued the Association, should be transferred to the national level ${ }^{29}$.

35 Procedurally, an institution strongly attached to the Party, i.e. the Association of Industry and Commerce, attached to the United Front Department of the Central Committee of the CCP, was taken advantage of to put forward a resolution to a weighty central institution, the Political Consultative Conference. Private entrepreneurs and private economy was not mentioned by name. It seems to be a resolution of the Association that it has the sole aim of securing legal equality of the non-state economic sector earlier on decided by the Party. This, so the argument went, was last but not least in the interests of the national economy. As innovations always require a long discussion process, the existence of a concrete 'example' makes the achievement much easier.

And this example existed already in Canton. Following the genesis of that development, we found that after the Fourteenth Party Congress (which decided the legal equality of the public and non-public sectors) the Association of Industry and Commerce had put forward a proposal backed by entrepreneurs to the Political Consultative Conference of Canton. This proposal suggested putting the private and state-owned sectors on an equal footing, and finally gained the approval of a majority of deputies. After consultations between representatives of the city's leadership, of the Political Consultative Conference and of the Association of Industry and Commerce the resolution was passed on to the People's Congress of the city. Concurrently, the United Front Department of the city Party Committee was persuaded to prepare a respective 
resolution to the city's Party committee. Both the Party committee and the city government approved the respective document.

After the decision of the Fifteenth Party Congress that declared the private sector to be part of the socialist sector, Canton, following the line of the central leadership, released the Regulations Protecting the Legal Rights of Private Entrepreneurs ${ }^{30}$. This was primarily to protect the legal rights, the property, ownership, and the autonomous management of entrepreneurs. Yet such legal protection at the same time strengthens their social and political prestige, and is a protection against arbitrariness and infringements of rights by local authorities. As a first step this did not occur at the relatively abstract national or provincial level, but at the level of a city which for entrepreneurs is politically much closer. This action was so successful that the organised entrepreneurship proposed a corresponding protection at provincial level that was finally negotiated with the provincial government. In July 1999 the respective regulation became operative ${ }^{31}$. Thus, by the same procedure, the Canton regulations were transferred to the provincial level, and Guangdong became the first province legally protecting specific rights of private entrepreneurs.

The development of this legislation reveals that there exists an organised and strategic associational policy of entrepreneurs. As such acts (legal equality) concern the interests of all entrepreneurs, this may be considered as a strategic policy in the interests of the entire social group of entrepreneurs. Such an interaction of formal and informal influences, combining various interests confirms Tanner's thesis of the existence of an organised anarchy.

39 The policy of petitions is a further example of deliberate and strategic action. Zhongguo Gongshang Bao for instance reported on petitions of deputies of the Political Consultative Conference at its spring session in 1998. Besides the revision of existing regulations for the private sector, drafts were put forward demanding more farreaching rights for attracting foreign investment, going public, and employment. Other deputies called for special 'offices for small and medium enterprises' that in future should be responsible for the administration of the private sector. They should elaborate the policies and legal regulations for this sector and look after the protection of its rights and their implementation, the obtaining of credits, information supply, further education, product advertisement, problem solutions, administration of entrepreneurial associations as well as adjusting the relationship vis-à-vis state- and collectively-owned enterprises ${ }^{32}$.

Contrary to the State Bureau for Administration of Industry and Commerce which currently is responsible for the administration of the private sector, such offices would, among other things, exclusively take care of private enterprises. Due to various interconnections between authorities and entrepreneurs, it could be used by the latter to enforce interests via the authorities and thus improve bargaining power vis-à-vis the bureaucracy. Other entrepreneurs appealed for the establishment of Party organisations within enterprises and the accepting of more entrepreneurial Party members (aim: 'to reinforce the function of the Party in private enterprises') ${ }^{33}$. Such a proposal was supported by areas of entrepreneurship. The reason was that a corresponding decision would have made it easier to accept entrepreneurs as Party members which in fact was not yet permitted, but widely practiced at that time. Thus, it would have been much easier for entrepreneurs to join Party networks, and consequently this would have increased the political acceptance of the private sector. 
41 In sum, currently the status quo shows that entrepreneurs primarily are concerned with the extension and protection of their economic rights as well as with the stabilisation of their business. In order to reduce uncertainty and to minimise transaction costs, they are interested in strengthening law and law security. This, at present, determines their political-strategic performance. This is certainly not unusual, as the enterprise is the basis of an entrepreneur's livelihood. A Chinese survey among entrepreneurs asking for their pivotal concern revealed that the principal concern was the development of their business. The second largest concern was the irksome problem of guanxi (guanxi mafan), third came corruption ${ }^{34}$. This demonstrates that the existence of those system-endemic problems are by no means part of a 'Chinese enterprise culture', but is rather conceived as a tremendous burden.

From a political point of view it might be questionable to speak already of an unambiguous 'strategic acting' of entrepreneurs, as such an acting would have been politically goal-oriented and had to be pursued in an organised manner. Accordingly, co-operations and agreements with other entrepreneurs, establishing and mobilising connections and networks as well as political activities in formal institutions (Party, People's Congresses, etc.) entirely serve the purpose of having an impact on the framework and to arrange the situation of the entrepreneurs and their enterprises as favourably as possible. This is also true for the political arena, albeit the organisation of participation currently is a crucial strategic aim. The organisational media for this are the existing associations which in the framework of state and Party policy cautiously define economic objectives at local and national level. This includes demands such as those that the Association of Private Enterprises (which is under the Bureau for the Administration of Industry and Commerce) should be turned into an independent juridical person' ${ }^{35}$ acting as a purely autonomous interest organisation of private entrepreneurs without any interference from the authorities ${ }^{36}$. Membership in those associations should become voluntary, not enforced ${ }^{37}$.

Entrepreneurs and state capacity

43 I have examined how entrepreneurs are continuously attempting to alter the framework and direction of state capacity. Reform and liberalisation processes were principal preconditions for that. The latter has restructured the political priorities and goal orientation and enabled new social actors to articulate interests in a more beneficial manner, has reinforced their bargaining power and thus their impact on state capacity. Thus, entrepreneurs increasingly were discerned as a principal element of the socialist system and no longer as a political opponent or a politically doubtful group. Last but not least the promotion of the private sector and entrepreneurship was accepted in the interests of modernisation. Strategic acting, containing formal and informal features, emerged by means of organisation. This did not weaken state capacities, but in turn improved them.

Recalling the above-mentioned five elements of state capacity (legitimacy, regulating and controlling capacity, resources for enforcement, bargaining capacity and learning capacity), the following could be ascertained: The legitimacy in terms of state and Party on the central level has increased due to political and legal acceptance of entrepreneurship by the central political leadership, though entrepreneurs are highly critical vis-à-vis local authorities. Our own surveys among entrepreneurs support this critical view ${ }^{38}$. 

regulation has grown as the state has not only accepted the existence of entrepreneurial associations, but also succeeded in including them in a corporatist manner. The personnel policy within the entrepreneurs' associations and their inclusion in political institutions (People's Congresses, Political Consultative Conferences, Village Administration Committees) as well as Party membership and the establishing of Party organisations in private enterprises are important resources for enforcement, though the effects of those matters remain to be seen. Our own investigations prove that entrepreneurs use official positions and party membership in a strategic way and, where Party organisations exist, dominate them in their enterprises. negotiate rights and patterns of participation. In addition, the state displayed its learning capacity or readiness to learn by means of his supportive policies towards the private sector and entrepreneurs. I argue that the revision of the framework and of the direction of state capacity is accepted by the state, as long as state capacity is not principally put into question by entrepreneurs, for instance by the demand of changing the political system. This is the intention, as the Party leadership is hopefully to reinforce state capacity instead of weakening it.

That the goal-orientation and direction of state capacity has changed is proved by the fact that meanwhile entrepreneurs are accepted as equal players, that their entrepreneurial rights are protected, that interest associations are admitted and Party membership is guaranteed. As I have shown above, the interaction of strategic acting of an organised entrepreneurship on the one side and a political leadership accepting the strategic and transformational operating of entrepreneurs on the other generated this change of direction. The political leadership has permitted and tolerated that entrepreneurs influence policies in their own interests and thus participate politically. Last but not least this is an expression of the fact that the political leadership no longer may be perceived as a representative of a policy defined by class interests, but increasingly as an autonomous force acting in the interests of all social groups or in the interests of the nation. Therefore, the above-mentioned concept of the existence of an embedded autonomy, according to which the state acts independently of particular interests, but concurrently finds itself embedded in distinct social relations that link state and society and make the implementation of policies possible, proves right in our context.

The acceptance of the strategic and transformational potential of entrepreneurs and their inclusion in political bargaining processes by Party and state is to be seen as a direct expression of the embedded autonomy. Thus, state capacity gained acceptance among entrepreneurs, too. Where a state protects their rights and proves to be capable to learn, entrepreneurs acknowledge that a state possesses legitimate state capacity. Concurrently, entrepreneurs establish 'advocacy coalitions' in order to better impact upon the policy process ${ }^{39}$.

49 Certainly, the capacity pattern exhibits an ambiguous picture: from the perspective of actors (entrepreneurs) as well as of the central state, capacity has increased. Yet the strategy of entrepreneurs alters the framework and its direction. It will be the task of future research to examine the outcome of this ratio and to define the consequences for the political system. 


\section{NOTES}

1.Fritz W. Scharpf, Interaktionsformen. Akteurzentrierter Institutionalismus in der Politikforschung, Opladen, Leske and Budrich, 2000, pp. 17-23.

2.Kjeld E. Brodsgaard and Susan Young, "Introduction: state capacity in East Asia", in: Broodsgaard and Young eds., State Capacity in East Asia, Oxford et al., Oxford University Press, 2000, pp. 4ff.

3.See Peter Dauvergne ed., Weak and Strong States in Asia-Pacific Societies, St. Leonards, Allen and Unwin, 1998, pp. 2-5.

4.Linda Weiss, The Myth of the Powerless State. Governing the Economy in a Global Era, Cambridge, Oxford, Polity Press, pp. 15ff.

5.Cf. Peter B. Evans, Embedded Autonomy: States and Industrial Transformation, Princeton, Princeton University Press, 1995.

6.Cf. Ernst B. Haas, When Knowledge is Power. Three Models of Change in International Organizations, Berkeley, Los Angeles, Oxford, University of California Press, 1990, pp. $25,26$.

7.According to Chinese classifications private entrepreneurs are businessmen who possess a non-public enterprise employing more than seven people. More on that: Thomas Heberer, "The Role of Private Entrepreneurs for Social and Political Change in the People's Republic of China and Vietnam", in: Thomas Menkhoff and Solvay Gerke eds., Chinese Entrepreneurship and Asian Business Networks, London and New York, RoutledgeCurzon, 2002, pp. 100-128.

8.See e.g. Hans-Dieter Evers and Tilman Schiel, Tilman, Strategische Gruppen. Vergleichende Studien zu Staat, Bürokratie und Klassenbildung in der Dritten Welt, Berlin, Reimer, 1988, pp. 10ff.; Hans-Dieter Evers, "Macht und Einfluss in der Entwicklungspolitik. Neue Ansätze zur Theorie Strategischer Gruppen”, in: Entwicklung und Zusammenarbeit, 1, 1997, pp. 15-17.

9.Evers 1997, p. 16.

10.Hans-Dieter Evers, “Globale Macht: Zur Theorie strategischer Gruppen”. Working Paper No 322 of the Sociology of Development Research Centre, Bielefeld, University of Bielefeld, 1999, p. 2.

11.Similarly Li Fang, The Social Organization of Entrepreneurship: The Rise of Private Firms in China (Diss.), Ann Arbor, UMI, 1998, pp. 87, 88.

12.Cf. Thomas Heberer, Unternehmer als Strategische Gruppen. Zur sozialen und politischen Funtion von Unternehmern in China und Vietnam, Hamburg, Institut für Asienkunde, 2001; T. Heberer, Private Entrepreneurs in China and Vietnam. Social and Political Functioning of Strategic Groups, Leiden, Brill, 2003 (forthcoming).

13.Cf. K. J. Radford, Strategic and Tactical Decisions, New York, North York, Springer, 1988, pp. $127 \mathrm{ff}$.

14.See also Andrew Pettigrew, Ewan Ferlie and Lorna McKee, Shaping Strategic Change. Making Change in Large Organizations, London et al., Sage, 1992, pp. $19 \mathrm{ff}$.

15.So Suzanne Keller, Beyond the Ruling Class. Strategic Elites in Modern Society, New York, Random House, 1963, p. 154.

16.Wei Jiafu, “Qiyejia xuyao shenme suzhi?" (Which qualities do entrepreneurs need?), in: Renmin Ribao (People’s Daily), December 27th 1999. 
17.John P. Neelsen, "Strategische Gruppen, Klassenbildung und Staat in der Peripherie. Eine Kritik des Bielefelder Ansatzes", in: Kölner Zeitschrift für Soziologie und Sozialpsychologie, 40, 1988, pp. 284-315; J.P. Neelsen, "Determinismus, Teleologie, Mystifizierung? Zum Empirismus des Konzepts der strategischen Gruppen. Eine Duplik", in: Kölner Zeitschrift für Soziologie und Sozialpsychologie, 41, 1989, pp. 555-562; Erhard Berner, "Strategische Cliquen und Proto-Klassen", Working Paper No. 158 of the Sociology of Development Research Centre, Bielefeld, University of Bielefeld, 1991 or Gunter Schubert, Rainer Tetzlaff and Werner Vennewald, Demokratisierung und politischer Wandel. Theorie und Anwendung des Konzeptes der strategischen und konfliktfähigen Gruppen, Münster, LIT, 1994, pp. 64ff. take a critical approach.

18.Mancur Olson, The Logic of Collective Action. Public Goods and the Theory of Groups, Cambridge/Mass., London, Harvard University Press, 1977, pp. 50, 51. 19.Bert Klandermans, "How Group Identification Helps to Overcome the Dilemma of Collective Action", in: American Behavioral Scientist, 5, 2002, p. 887.

20.At a conference on economic administration of the private sector, it was explicitly stated that the time of political control was over. Crucial in future would be economic control, compare e.g. Zhongguo Gongshang Bao (China's Industry und Commerce Daily), October 23rd 1998.

21.Cf. Thomas von Winter, "Schwache Interessen: Zum kollektiven Handeln randständiger Gruppen", in: Leviathan, 4, 1997.

22.V. Taylor and N. E. Whittier, "Collective identity in social movement communities: Lesbian feminist mobilization", in: A. Morris and C. McClurg Mueller eds., Frontiers of social movement theory, New Haven, Yale University Press, 1992, p. 172.

23.An advisory institution comprised of social personalities and representatives of various social groups that exists parallel to the People's Congresses at all administrative levels.

24.The interview was conducted in July 1999. The interviewee asked that his name not be mentioned.

25.Zhongguo Gongshang Bao, November 21st 1997.

26.Cf. e.g. Kanishka Jayasuriya, "The Rule of Law and Capitalism in East Asia", in: The Pacific Review, 3, 1996.

27.Similar: Rolf Herno, State-Private Business Interaction in Vietnam: State

Management of Network Capitalism. Paper presented to the 50th Annual Meeting of the Association of Asian studies, Washington, D.C., March 26th-29th 1998, p. 10.

28.Murray S. Tanner, The Politics of Lawmaking in Post-Mao China. Institutions, Processes and Democratic Prospects, Oxford, Clarendon, 1999, pp. 28ff. More on Garbage Can Theorie: Michael Cohen, James G. March and Johan P. Olsen, "A Garbage Can Model of Organizational Choice”, in: Administrative Science Quarterly, 1, 1972, pp. $1-26$.

29.Zhongguo Gongshang Bao, March 6th 1998.

30.Zhongguo Gongshang Bao, October 31st 1997.

31.Zhongguo Gongshang Bao, July 9th 1999.

32.On entrepreneurial associations cf. Christopher Earle Nevitt, "Private Business Associations in China: Evidence of Civil Society or Local State Power", in: The China Journal, July, 1996, pp. 25-43; Jonathan Unger, "Bridges: Private Business, the Chinese Government and the Rise of New Associations", in: The China Quarterly, September, 1996, pp. 795-819; Thomas Heberer, "Die Rolle von Interessenvereinigungen in autoritären Systemen: Das Beispiel Volksrepublik China", in: Politische 
Vierteljahresschrift, No 2, 1996, pp. 277-297; Sophia Woodman, “Less Dressed Up as More? Promoting Non-Profit-Making Organizations by Regulating Away Freedom of Association", in: China Perspectives, March-April, 1999, pp. 17-27; Kenneth W. Foster, "Embedded within State Agencies: Business Associations in Yantai", in: The China Journal, January, 2002, pp. 41-66.

33.Zhongguo Gongshang Bao, March 20th 1998.

34.Zhongguo Qiyejia (China's Entrepreneurs), No. 9, 1999, p. 78.

35.Cf. Zhongguo Gongshang Bao, November 20th 1998.

36.Ibid.

37.Zhongguo Gongshang Bao, March 19th 1999.

38. Heberer 2001, pp. 215ff; $349 \mathrm{ff}$.

39.Cf. Ian Greener, "Social Learning and Macroeconomic Policy in Britain", in: International Public Policy, 2, 2001, p. 137. 